The Third World in Global Development 
Also by Ankie M. M. Hoogvelt

The Sociology of Developing Societies 


\section{The Third World in Global Development}

Ankie M. M. Hoogvelt

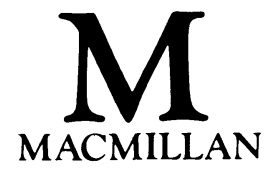


All rights reserved. No reproduction, copy or transmission of this publication may be made without written permission.

No paragraph of this publication may be reproduced, copied or transmitted save with written permission or in accordance with the provisions of the Copyright, Designs and Patents Act 1988, or under the terms of any licence permitting limited copying issued by the Copyright Licensing Agency, 90 Tottenham Court Road, London W1P 9HE.

Any person who does any unauthorised act in relation to this publication may be liable to criminal prosecution and civil claims for damages.

First published 1982 by

THE MACMILLAN PRESS LTD

Houndmills, Basingstoke, Hampshire RG21 2XS

and London

Companies and representatives

throughout the world

ISBN 978-0-333-27682-2 ISBN 978-1-349-16777-7 (eBook)

DOI 10.1007/978-1-349-16777-7

A catalogue record for this book is available

from the British Library.

Reprinted 1983, 1984, 1985, 1987, 1989, 1991, 1994 


\section{Contents}

Foreword and Acknowledgements

vii

List of Abbreviations

ix

List of Tables and Figures

xi

Introduction and Summary

\section{PART ONE: FACTS}

1 The Changing World Economy 15

The Economic Differentiation of the Third World 15

The Petro-dollar Lubrication of the World Economy $\quad 45$

The Internationalisation of Production 56

2 Political Responses: The Rise and Fall of Third World Solidarity

The History of Third World Solidarity

The New International Economic Order:

Confrontation

80

The New International Economic Order:

Conciliation

Equity in the South: from Global Keynesianism to

Global Social Democracy - the Basic Needs

Strategy

\section{PART TWO: THEORIES}

3 Social Evolution and Development: The Bourgeois Liberal Tradition

Nineteenth-century Evolutionary Theories

Twentieth-century Neo-evolutionary Theories

The Modern Stage of Social Evolution

Modernisation Theories 
4 From Modernisation to Global Growth: New Directions in the Bourgeois Liberal Tradition

World Futures Theories: Methodology

World Futures Theories: Themes and Issues

5 Theories of Social Evolution and Development:

The Marxist Tradition

The Concept of Mode of Production and Historical Materialism

The Capitalist Mode of Production

Theories of Imperialism, Dependency and Underdevelopment

6 From Dependency to Global Political Economy:

New Directions in the Marxist Tradition

Re-examining the Concept of 'Exploitation': the Articulation of Modes of Production

The 'Productionist' Argument: Dependencyassociated Development, Historical Specificity and Class Reductionism

The 'Circulationist' Argument: Deepening of the

World System Perspective and Economic

Reductionism

The Global Political Economy of Samir Amin

Conclusions

Name Index 


\section{Foreword and Acknowledgements}

Like any other textbook this one is, characteristically, a book about other books. At the present time, when financial resources are pulled out of higher education and stuffed into nuclear warheads, those few of us who (still) work in academic institutions are privileged to have access to the world of ideas. But even this privilege is a blessing increasingly mixed with frustration.

Gone are the days when new acquisitions were as common to a university library as newspapers to a breakfast table. With pin-money for a book grant our reading material has become strictly rationed: some eight books per course per year if we are lucky. New journals are no longer purchased, existing subscriptions are terminated. So how do we keep up with new developments in our respective academic fields? How did I, for example, manage to write a book about books? Somewhat unconventionally I should like to acknowledge two sources of help without which this book would never have been written. One is the documentation department of the Institute of Social Studies in The Hague, Netherlands. Although I ended my employment for that (richly financed) institute some twelve years ago, the department has continued to send me their valuable catalogues and abstracts, regularly and free of charge. The other source of assistance has come from the staff of the inter-library loan section of the library of my own university, at Sheffield. I especially wish to thank Ms Julia Dagg, who has always promptly and cheerfully processed my numerous requests for books, relentlessly chasing after works which I had often badly referenced and which sometimes did not even exist! 
The thick crop of statistical evidence in Chapter 1 of the book is not the fruit of my labour only, though naturally I alone take responsibility for any errors. I thank Roger Richards of the university's computing department and Peter Jones, my one-time and temporary research assistant, for the good cheer with which they have processed a lot more material than I could in the end incorporate. When my own grand statistical ventures failed, it was, however, very nice to have available for reproduction the statistical tables produced by those very useful international number-crunchers: the World Bank and the OECD.

Sheffield

October 1981

Ankie M. M. Hoogvelt

The author and publishers wish to thank the following who have kindly given permission for the use of copyright material:

Bank for International Settlements for a table from the 50th Annual Report (1980); Oxford University Press for a table from Redistribution With Growth by Hollis Chenery et al. (1974); the World Bank for tables from the 1980 Annual Report and Prospects for Developing Countries. 


\section{List of Abbreviations}

DAC Development Assistance Committee (of the OECD)

DC Developed Countries

ECLA (UN) Economic Commission for Latin America

ECOSOC (UN) Economic and Social Committee

ECSIM European Centre for Study and Information on Multinational Corporations

EEC European Economic Community

GATT General Agreement on Tariffs and Trade

GDP Gross Domestic Product

GNP Gross National Product

GSP General System of Preferences

IBRD International Bank for Reconstruction and Development (the World Bank)

ICP International Commodity Program

IDA International Development Association (of the IBRD)

IFAD International Fund for Agricultural Development

ILO International Labour Organisation

IMF International Monetary Fund

LDCs Less Developed Countries 
MNC Multinational Company (Corporation) (Note: this abbreviation is also sometimes used to describe Most Needy Countries. The latter is a classificatory term used in UN documents to refer to those countries which are believed to be most in need of development assistance.)

MOP Mode of Production

MSA Most Seriously Affected (official UN classification of those countries most seriously affected by the oil price hikes)

NIC Newly Industrialising Country

NIEO New International Economic Order

ODA Official Development Assistance (from OECD member countries)

OECD Organisation for Economic Co-operation and Development

OPEC Organisation of Petroleum Exporting Countries

SDR Special Drawing Rights

UDC Under-Developed Countries

UNCTAD United Nations Conference on Trade and Development

UNDP United Nations Development Program

UNIDO United Nations Industrial Development Organisation 


\section{List of Tables and Figures}

Tables

1.1 The countries of the world (GNP per capita, average annual rates of growth, and population)

1.2 Growth of gross national product and gross national product per capita 1960-80 (average annual percentage growth rates at 1977 prices)

1.3 Distribution of GDP (per cent)

1.4 Growth of production of manufacturing sector (average annual growth rates, per cent)

1.5 Composition of merchandise exports from developing countries (per cent)

1.6 Share of manufactures in exports from developing countries when excluding oil

1.7 Percentage share of manufactures in exports by country group

1.8 Average annual growth rates of imports and terms of trade of fuel and non-fuel mineralexporting countries

1.9 Importance of developing countries as markets for industrial countries' exports of manufactures, 1973 and 1978 (percentage shares in total exports)

1.10 Cross-classification of countries by income level and equality

1.11 The location of absolute poverty by income groups, 1975

1.12 Oil-exporting countries: estimated deployment of investible surpluses, 1974-9 (billions of US dollars) 
1.13 Global current account, 1973-6 (US billion dollars)

1.14 Debt outstanding and disbursed (eighty-one countries, at current prices, selected years, US billion dollars)

1.15 Total net resource receipts of developing countries from all sources (billions of US dollars)

1.16 Total external public debt outstanding (including undisbursed), 1972-8, of all developing countries (millions of US dollars)

1.17 Accumulated stock of direct investment in developing countries by major industrial sector (1966 and 1974)

1.18 Dependence on selected imported industrial raw materials (imports as a percentage of consumption)

1.19 LDC share in world trade for selected commodities (in percentages)

1.20 Stock of private overseas direct investments in developing countries, 1977 (principal hosts)

1.21 Share of multinational companies in the exports of manufactures from selected developing countries

Figures

1.1 Frequency distribution of GNP per capita by countries and population, 1967

1.2 Frequency distribution of GNP per capita by countries and population, 1978

3.1 The stages of social evolution

3.2 The structure of modern societies 